Мелиорация и гидротехника. 2021. Т. 11, № 4. С. 346-359.

Land Reclamation and Hydraulic Engineering. 2021. Vol. 11, no. 4. P. 346-359.

ГИДРАВЛИКА И ИНЖЕНЕРНАЯ ГИДРОЛОГИЯ

Научная статья

УДК 626.814

doi: 10.31774/2712-9357-2021-11-4-346-359

Эксплуатация и использование Пролетарского водохранилища

Юрий Михайлович Косиченко ${ }^{1}$, Виктория Федоровна Талалаева ${ }^{2}$

1,2Российский научно-исследовательский институт проблем мелиорации, Новочеркасск, Российская Федерация

${ }^{1}$ kosichenko-11@mail.ru

${ }^{2}$ vika-silchenko@mail.ru

Аннотация. Цель: исследования Пролетарского водохранилища заключается в использовании Ново-Манычской дамбы для регулирования режима работы западного и восточного отсека с водорегулирующим сооружением между ними. Материалы и методы: рассматриваются вопросы использования и регулирования водных ресурсов Пролетарского водохранилища, в т. ч. Ново-Манычской дамбы, разделяющей водохранилище на западный и восточный отсеки. Результаты. Западный отсек Пролетарского водохранилища расположен между Пролетарским гидроузлом и Ново-Манычской дамбой и представляет собой плес длиной около 20 км. В нормальных условиях эксплуатации через водорегулирующее сооружение в Ново-Манычской дамбе происходит отток воды из западного отсека в восточный. При этом основное количество воды в западный отсек поступает по р. Егорлык, оно сбрасывается через водоспуск плотины Пролетарского гидроузла в Веселовское водохранилище. Восточный отсек Пролетарского водохранилища ограничивается Ново-Манычской дамбой с западной стороны и глухой дамбой с восточной стороны. Водные ресурсы Пролетарского водохранилища по первоначальному проекту использовались для судоходства, орошения, рыбного хозяйства, гидроэнергетики. Фактическое использование водных ресурсов водохранилища для судоходства практически отсутствует, орошение не осуществляется, рыбное хозяйство утратило свое значение, а гидроэнергетика выведена из эксплуатации. Используется только рекреация: санаторий «Маныч», около 30 охотничьих хозяйств, заповедники «Ростовский» и «Черные Земли», памятник природы «Приманычская степь». Сеть водоемов и оз. Маныч-Гудило являются водно-болотным угодьем, имеющим международное значение в качестве обитания водоплавающих птиц. Выводы. В статье рассматриваются вопросы использования и регулирования водных ресурсов Пролетарского водохранилища и Ново-Манычской дамбы, разделяющей водохранилище на западный и восточный отсеки.

Ключевые слова: Пролетарское водохранилище, Ново-Манычская дамба, озеро Маныч-Гудило, водный баланс, Пролетарский гидроузел

\title{
HYDRAULICS AND ENGINEERING HYDROLOGY
}

Original article

\section{The Proletarskiy reservoir operation and usage}

\section{Yuriy M. Kosichenko ${ }^{1}$, Victoria F. Talalaeva ${ }^{2}$}

${ }^{1,2}$ Russian Scientific Research Institute of Land Improvement Problems, Novocherkassk, Russian Federation

${ }^{1}$ kosichenko-11@mail.ru

${ }^{2}$ vika-silchenko@mail.ru

(C) Косиченко Ю. М., Талалаева В. Ф., 2021 
Abstract. Purpose: the studies of the Proletarskiy reservoir is to use the Novo-Manych dam in regulating the operation of the western and eastern sections with a water regulating structure between them. Materials and methods: the issues on use and regulation of water resources of the Proletarsk reservoir are considered, including the Novo-Manych dam, which divides the reservoir into the western and eastern sections. Results. The western section of the Proletarskiy reservoir is located between the Proletarskiy hydroelectric complex and the Novo-Manych dam and is a stretch of about $20 \mathrm{~km}$. Under normal operating conditions, water flows from the western section to the eastern one through the water regulating structure in the Novo-Manych dam. At the same time, the main amount of water enters the western section along the river Egorlyk, it is discharged through the drain of the Proletarskiy hydroelectric dam into the Veselovskoye reservoir. The eastern section of the Proletarskiy reservoir is limited by the Novo-Manych dam on the western side and a blind dam on the eastern side. According to the initial project, the water resources of the Proletarskiy reservoir were used for shipping, irrigation, fisheries, and hydropower. The actual use of the reservoir's water resources for navigation is practically absent, irrigation is not performed, the fishery has lost its importance, and the hydropower industry has been out of service. Only recreation is used: the sanatorium "Manych", about 30 hunting farms, the "Rostovsky" and "Chernye Zemli" reserves, the natural monument "Primanychskaya steppe". The network of reservoirs and Manych-Gudilo lake is a wetland of international importance as a habitat for waterfowl. Conclusions. The issues of the use and regulation of water resources of the Proletarskiy reservoir and the Novo-Manych dam, dividing the reservoir into the western and eastern sections are considered.

Keywords: the Proletarskiy reservoir, the Novo-Manych dam, the Manych-Gudilo lake, water balance, the Proletarskiy hydroelectric complex

Введение. Пролетарское водохранилище образовано Пролетарским гидроузлом (далее - Пролетарский ГУ) путем затопления долины р. Западный Маныч и ряда озер Манычской котловины. Пролетарский ГУ расположен у западного конца затопленного лимана Рыбосол, к северо-востоку от устья р. Средний Егорлык. Выше устья р. Егорлык Пролетарское водохранилище рассечено Ново-Манычской дамбой на два отсека - западный и восточный (оз. Маныч-Гудило) [1, 2].

Пролетарский ГУ состоит из земляной плотины с донным водоспуском и приплотинного однокамерного шлюза. Плотина предназначена для создания судоходных условий и регулирования стока. Шлюз предназначен для пропуска судов [3]. Чаша водохранилища расположена на территории трех субъектов Российской Федерации: Ростовской области (Орловский, Пролетарский и Сальский районы), Республики Калмыкия (Приютинский и Яшалтинский районы) и Ставропольского края (Апана- 
сенковский район). Общая длина Пролетарского водохранилища - 150 км, в т. ч. западного отсека - 20 км, восточного отсека - 130 км $[4,5]$.

Западный отсек Пролетарского водохранилища расположен между Пролетарским ГУ и Ново-Манычской дамбой и представляет собой плес длиной около 20 км, шириной 1-3 км с плоским дном. В нормальных эксплуатационных условиях через водорегулирующее сооружение в НовоМанычской дамбе происходит отток воды из западного в восточный отсек. В многоводные годы уровень воды в восточном отсеке превышает уровень воды в западном, в результате чего возможен перелив воды из восточного отсека в западный. Основное количество воды в западный отсек поступает по р. Егорлык, а сбрасывается она через водовыпуск плотины Пролетарского ГУ в Веселовское водохранилище [2].

Восточный отсек Пролетарского водохранилища ограничивается Ново-Манычской дамбой с одной (западной) стороны и глухой дамбой с другой (восточной) стороны. Восточный отсек по морфологическим особенностям делится на три участка: западный, центральный и восточный. Границы между ними проходят по заливам, в которые впадают балка Хоревая (залив Балка Хоревая) на западе и р. Кираста на востоке (залив Маныч). В акватории восточного отсека расположен ряд островов (преимущественно небольших размеров). Острова в основном плоские, незначительно возвышающиеся над поверхностью воды [1]. Общая схема Пролетарского водохранилища представлена на рисунке 1.

В восточный отсек Пролетарского водохранилища вода поступает из западного отсека через водорегулирующее сооружение Ново-Манычской дамбы (рисунок 2), от р. Калаус, а также от балок и рек, впадающих в восточный отсек с левого и правого склонов (Джалга, Дунда, Киста, Чикалда и др.). Восточный отсек является бессточным. Минерализация воды в восточном отсеке Пролетарского водохранилища в среднем составляет 12-20 г/дм³ , что исключает возможность использования ее для сельскохозяйственных и рыбохозяйственных нужд $[6,7]$. 


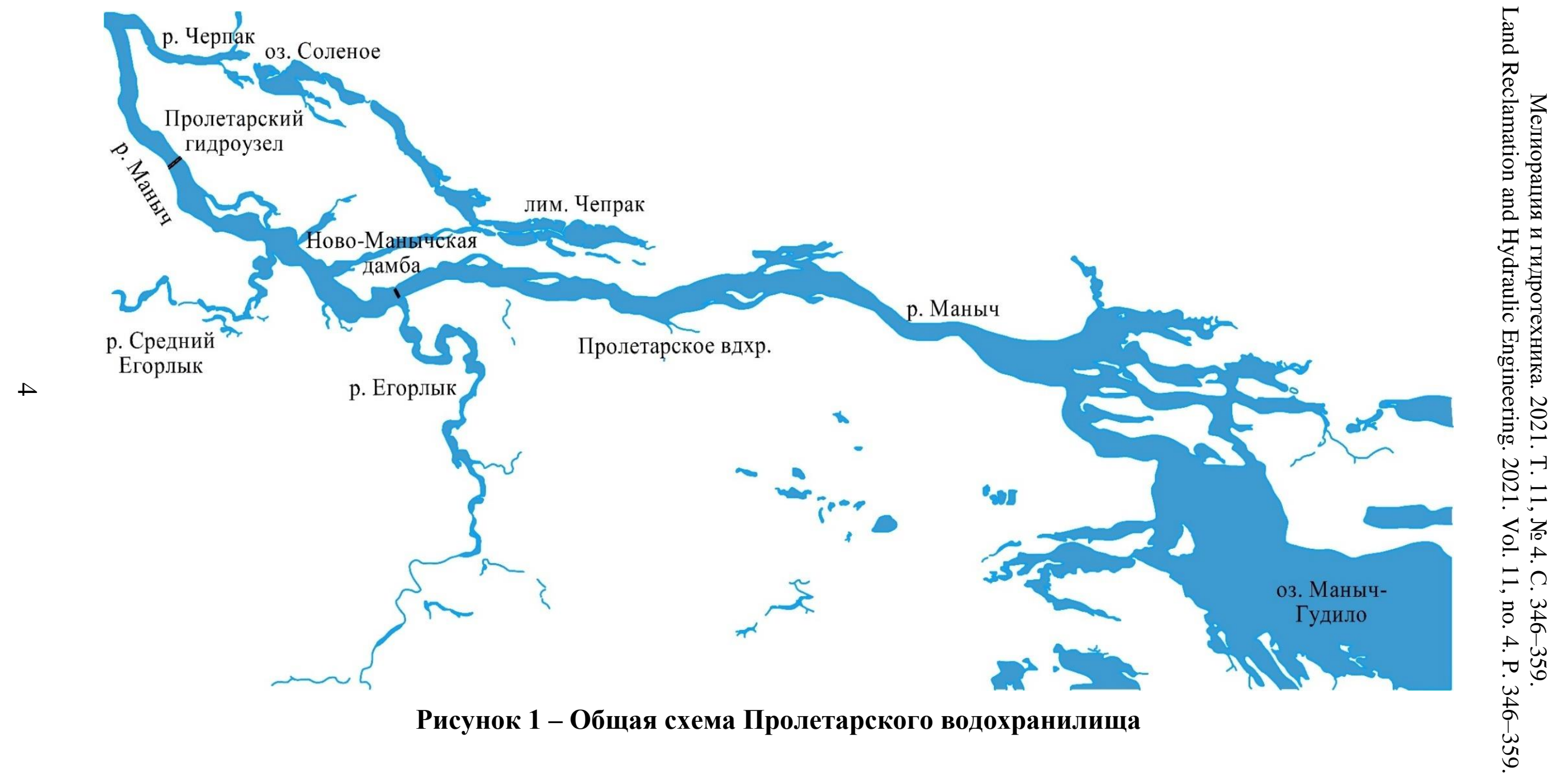


Мелиорация и гидротехника. 2021. Т. 11, № 4. С. 346-359.

Land Reclamation and Hydraulic Engineering. 2021. Vol. 11, no. 4. P. 346-359.

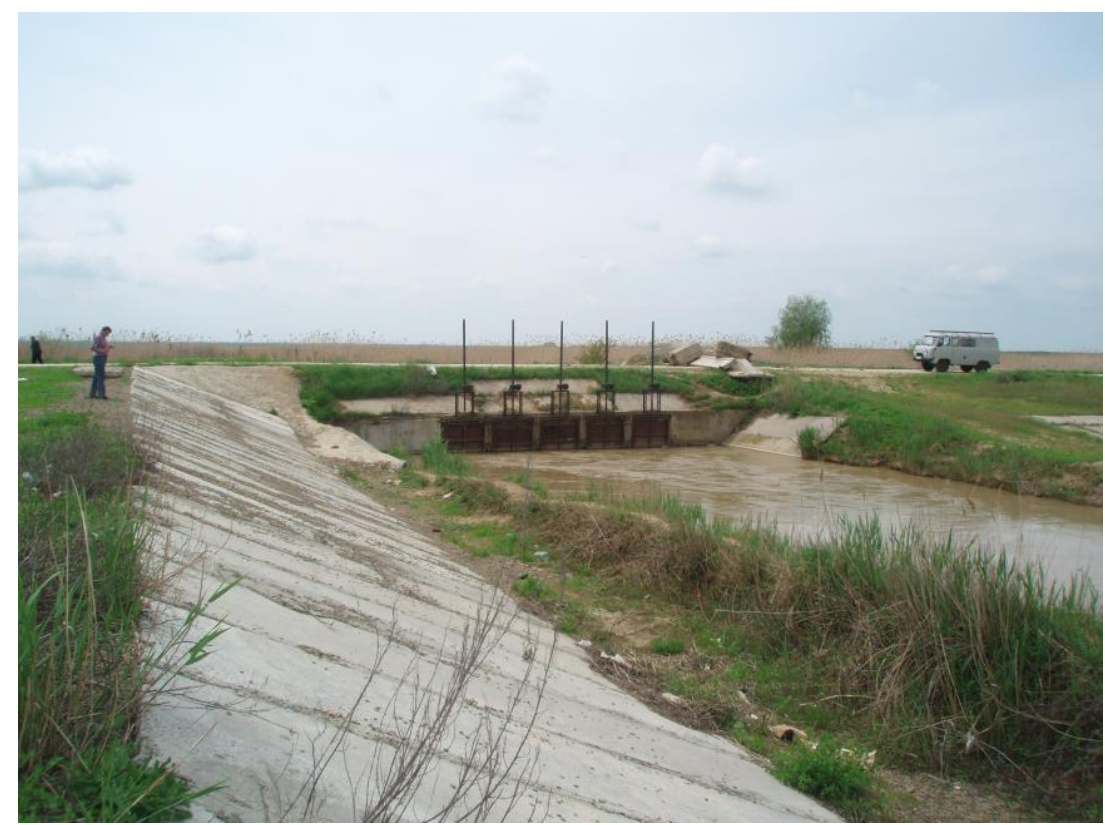

Рисунок 2 - Ново-Манычская дамба (автор фото Ю. М. Косиченко)

Пролетарское водохранилище равнинного типа, мелководное, западный отсек по объему относится к средним, восточный - к крупным водохранилищам. По генезису котловин западный отсек относится к русловым долинным, восточный - зарегулированное озеро-водохранилище. Вытянутая форма восточного отсека Пролетарского водохранилища способствует образованию сгонов и нагонов на его противоположных концах [8].

Цель работы заключается в изучении вопросов эксплуатации и использования водных ресурсов Пролетарского водохранилища и НовоМанычской дамбы.

Материалы и методы. Водные ресурсы Пролетарского водохранилища по первоначальному проекту использовались для следующих целей: судоходство, орошение, рыбное хозяйство (западный отсек - основное нерестилище промысловых рыб, восточный отсек - место нагула рыб), гидроэнергетика (Пролетарская гидроэлектростанция (далее - ГЭС)).

Фактическое использование водных ресурсов Пролетарского водохранилища $[7,9,10]$ :

- судоходство по Пролетарскому водохранилищу практически отсутствует. С 2004 г. пропуск судов через Пролетарский ГУ не осуществлялся; 
- орошение из Пролетарского водохранилища не осуществляется;

- рыбное хозяйство. В настоящее время Пролетарское водохранилище утратило свое значение как рыбопромысловый водоем. Промысловый лов рыбы полностью прекращен;

- гидроэнергетика. В 1972 г. ГЭС выведена из эксплуатации, а оборудование демонтировано;

- рекреация. В настоящее время на территории, прилегающей к Пролетарскому водохранилищу, расположены: санаторий «Маныч», около 30 охотничьих хозяйств, заповедники «Ростовский» и «Черные Земли», памятник природы «Приманычская степь» между правым берегом р. Егорлык и восточным отсеком Пролетарского водохранилища.

Пролетарское водохранилище, включая прилегающую к нему сеть водоемов и оз. Маныч-Гудило в пределах Ростовской области под общим названием угодья «Озеро Маныч-Гудило», является водно-болотным угодьем Ростовской области, имеющим международное значение в качестве мест обитания водоплавающих птиц [11].

Пролетарским филиалом Управления мелиорации земель и сельскохозяйственного водоснабжения по Ростовской области (далее - ФГБУ «Управление «Ростовмелиоводхоз») на Ново-Манычской дамбе с 1950 г. организованы постоянные наблюдения за стоком воды из западного отсека Пролетарского водохранилища в восточный. За весь период наблюдений происходит постоянный сброс воды из западного отсека в восточный (оз. Маныч-Гудило).

Восточный отсек Пролетарского водохранилища не используется как хозяйственный водоем и не участвует в регулировании стока в интересах функционирования комплекса отраслей народного хозяйства. В силу дефицитности водного баланса восточного отсека Пролетарского водохранилища для поддержания его эксплуатационных уровней предусматривается дотация из западного отсека водохранилища. В многоводные годы в слу- 
чае переполнения восточного отсека Пролетарского водохранилища сток через глухую Манычскую дамбу (в восточной части водохранилища) поступает в буферную емкость Чограйского водохранилища.

Пролетарское, Веселовское и Усть-Манычское водохранилища были построены в ходе попытки реализации водного пути (Кумо-Манычский канал) Азовское море - Каспийское море. В связи с этим основной задачей водохранилищ по проекту на момент создания являлось обеспечение судоходства.

Среди наиболее крупных притоков р. Западный Маныч можно выделить: левые притоки - р. Джалга, Егорлык, Средний Егорлык, Юла; приток справа - р. Чикалда. Между р. Западный Маныч и р. Сал в их низовьях существует соединяющая их протока Подпольная, далее протока Сусат, последняя имеет пересыхающий выход в р. Дон. Площадь бассейна р. Западный Маныч включает площади бассейнов р. Калаус, Егорлык, Средний Егорлык и ряда других малых рек. В настоящее время р. Калаус от р. Восточный Маныч отгорожена глухой дамбой с фиксированным порогом, и поэтому сток р. Калаус полностью попадает в р. Западный Маныч $[11,12]$.

Результаты и обсуждение. В результате образования трех крупных водохранилищ на р. Западный Маныч было создано ступенчатое непрерывное водное зеркало. С 1948 и 1955 г. в эти водохранилища вода подавалась из р. Кубани по р. Калаус, Егорлык и из р. Дон по Донскому магистральному каналу, что привело к изменению водного режима рек бассейна Западного Маныча, его гидрографии и опреснению воды.

Егорлык - самый крупный левый приток р. Западный Маныч, длина реки 448 км, площадь водосбора 15000 км². Речная сеть бассейна р. Егорлык развита сравнительно слабо, коэффициент густоты составляет 0,1-0,2 км/км². Речная сеть состоит в основном из временных водотоков. Постоянный сток имеют реки, берущие начало на Ставропольской возвышенности [13]. 
Основным источником питания рек в бассейне Западного Маныча являются талые снеговые воды, поэтому их водный режим характеризуется высоким весенним половодьем и низкой меженью в остальное время года. Доля весеннего стока (III-V) составляет около 70 \% от годового, сток летнеосеннего периода (VI-XI) 10-20 \% и зимнего (XII-II) 6-10\% [12, 14].

По водному режиму бассейн р. Западный Маныч в естественных условиях четко разделяется на шесть участков: 1) верховье - от устья р. Калаус до устья р. Егорлык; 2) средняя часть - от устья р. Егорлык до хутора Веселого; 3) нижняя часть - от хутора Веселого до впадения p. Западный Маныч в р. Дон; 4) левые и правые притоки р. Западный Маныч; 5) бассейн р. Егорлык; 6) бассейн р. Калаус. В таблице 1 приводятся сведения о площади водосбора в бассейне р. Западный Маныч.

\section{Таблица 1 - Площади водосбора р. Западный Маныч}

\begin{tabular}{|c|c|}
\hline & В тыс. км ${ }^{2}$ \\
\hline Створ & \begin{tabular}{|c|} 
Площадь \\
водосбора
\end{tabular} \\
\hline $\begin{array}{l}\text { р. Западный Маныч: створ исток - створ Пролетарского ГУ (без р. Калаус } \\
\text { и Большой Егорлык), в т. ч.: } \\
\text { - створ исток - створ Ново-Манычская дамба (восточный отсек); } \\
\text { - створ Ново-Манычская дамба - створ Пролетарский ГУ (западный отсек) }\end{array}$ & $\begin{array}{c}18,7 \\
15,5 \\
3,2\end{array}$ \\
\hline $\begin{array}{l}\text { р. Калаус: створ исток - створ устье р. Калаус (место впадения в р. Запад- } \\
\text { ный Маныч) }\end{array}$ & 9,7 \\
\hline $\begin{array}{l}\text { р. Большой Егорлык: створ исток - створ устье (место впадения в р. За- } \\
\text { падный Маныч) }\end{array}$ & 15,0 \\
\hline $\begin{array}{l}\text { p. Западный Маныч: створ исток - створ Пролетарского ГУ (в т. ч. p. Ка- } \\
\left.\text { лаус }\left(A=9700 \text { км}^{2}\right) \text { и Большой Егорлык }\left(15000 \text { км}^{2}\right)\right)\end{array}$ & 43,4 \\
\hline
\end{tabular}

Гидротехнические сооружения (далее - ГТС) водохранилищ на p. Западный Маныч состоят из комплекса ГТС напорных гидроузлов: Пролетарского, Веселовского и Усть-Манычского. В состав комплекса ГТС напорного фронта Пролетарского ГУ входят $[9,12]$ следующие.

1 Земляная плотина с донным водоспуском. Плотина относится к III классу сооружений. Длина по гребню (между наружными гранями устоев) глухой части - 960 м, водопропускной - 15,65 м. Составные части плотины: 
Мелиорация и гидротехника. 2021. Т. 11, № 4. С. 346-359.

Land Reclamation and Hydraulic Engineering. 2021. Vol. 11, no. 4. P. 346-359.

- понур представляет собой слой бетона 0,5 м, длина понура - 28,74 м;

- флютбет состоит из бетона слоем у башни водоспуска 2 м, выходная часть слоем 1,2 м, уложен на слой тощего бетона 0,15 м на бурой глине;

- рисберма состоит из 10 рядов забитых свай. Между сваями уложен Хворост 20 см с пригрузкой каменной наброской. Остальная часть вымощена камнем. Длина 36,4 м;

- устои, шахты, трубы, гаситель выполнены из железобетона.

2 Водосбросное сооружение. Расположено в теле плотины. Тип трехочковый башенный трубчатый донный водоспуск (три трубы квадратного сечения размерами $3,55 \times 3,55 \mathrm{~m}$ ).

3 Судоходный шлюз. Однокамерный, приплотинный с откосными стенами. Является третьей ступенью Манычской шлюзованной системы.

В состав ГТС Ново-Манычской дамбы входят дамба и водорегулирующее сооружение (таблица 2) [12].

\section{Таблица 2 - Основные параметры Ново-Манычской дамбы и водорегулирующего сооружения}

\begin{tabular}{|c|c|}
\hline $\begin{array}{c}\text { Наименование техниче- } \\
\text { ской характеристики и } \\
\text { сведений }\end{array}$ & Значение \\
\hline \multicolumn{2}{|r|}{ Ново-Манычская дамба } \\
\hline Тип сооружения & Дамба земляная насыпная \\
\hline Класс сооружения & IV \\
\hline Местоположение & 20 км от створа Пролетарского ГУ \\
\hline Длина по гребню, м & 1228 \\
\hline Ширина по гребню, м & 6,0 \\
\hline Материал сооружения & Грунт - суглинок \\
\hline $\begin{array}{l}\text { Откосы: } \\
\text { - заложение восточного } \\
\text { - заложение западного }\end{array}$ & $\begin{array}{l}1: 5 \\
1,25\end{array}$ \\
\hline Крепление откосов & Каменная отмостка, сборные железобетонные плиты \\
\hline Уровень безопасности & Нормальный \\
\hline \multicolumn{2}{|r|}{ Водорегулирующее сооружение } \\
\hline Тип сооружения & $\begin{array}{c}\text { Трубчатое, с портальным оголовком. Оборудовано плос- } \\
\text { кими затворами с ручными винтоподъемниками }\end{array}$ \\
\hline Класс сооружения & IV \\
\hline Местоположение & Устье р. Западный Маныч \\
\hline Количество сооружений & 2 \\
\hline Уровень безопасности & Нормальный \\
\hline
\end{tabular}


Мелиорация и гидротехника. 2021. Т. 11, № 4. С. 346-359.

Land Reclamation and Hydraulic Engineering. 2021. Vol. 11, no. 4. P. 346-359.

Восточный отсек Пролетарского водохранилища отделяется от Чограйского водохранилища (истока р. Восточный Маныч) глухой дамбой, соответствующей максимальному эксплуатационному уровню оз. МанычГудило.

Среднемноголетний укрупненный водный баланс водохранилищ в годовых объемах по результатам расчета водохозяйственного баланса по многолетнему ряду (за период 1950-2010 гг.) приводится в составе следующих статей: располагаемые водные ресурсы, безвозвратное изъятие стока, поступление воды в нижний бьеф (таблица 3 ).

\section{Таблица 3 - Среднемноголетний укрупненный водный баланс} Пролетарского водохранилища (1950-2010 гг.)

\begin{tabular}{|c|c|c|c|c|c|c|c|c|}
\hline \multicolumn{9}{|c|}{ 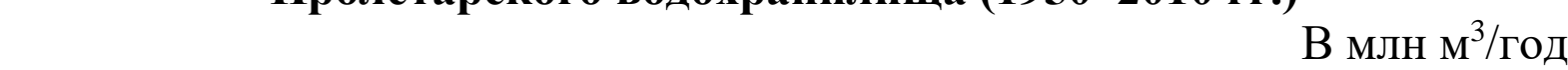 } \\
\hline \multicolumn{9}{|c|}{1 Располагаемые водные ресурсы водохранилищ (в среднем за многолетие) } \\
\hline Всего & \multicolumn{2}{|c|}{$\begin{array}{c}\text { Поступление } \\
\text { смешанных ку- } \\
\text { банских вод } \\
\text { (брутто) по } \\
\text { р. Егорлык }\end{array}$} & \multicolumn{2}{|c|}{$\begin{array}{c}\text { Поступление из } \\
\text { Донского маги- } \\
\text { стрального ка- } \\
\text { нала (ДМК) }\end{array}$} & $\begin{array}{l}\text { Боковая } \\
\text { приточ- } \\
\text { ность на } \\
\text { участке }\end{array}$ & $\begin{array}{l}\text { Грун- } \\
\text { товые } \\
\text { воды }\end{array}$ & \multicolumn{2}{|c|}{$\begin{array}{c}\text { Подземные во- } \\
\text { ды, включая до- } \\
\text { тацию за счет } \\
\text { подземных во- } \\
\text { доотводов }\end{array}$} \\
\hline 1204,03 & \multicolumn{2}{|c|}{1078,09} & \multicolumn{2}{|c|}{50,77} & 54,14 & 0,37 & & \\
\hline \multicolumn{9}{|c|}{$\begin{array}{c}2 \text { Безвозвратное водопотребление и использование водных ресурсов водохранилищ } \\
\text { (в среднем за многолетие) }\end{array}$} \\
\hline Всего & $\begin{array}{l}\text { Коммуналь- } \\
\text { но-бытовое } \\
\text { водоснаб- } \\
\text { жение }\end{array}$ & \multicolumn{2}{|c|}{$\begin{array}{l}\text { Промыш- } \\
\text { ленное водо- } \\
\text { снабжение }\end{array}$} & \multicolumn{2}{|c|}{$\begin{array}{c}\text { Сельскохозяй- } \\
\text { ственное водо- } \\
\text { снабжение }\end{array}$} & \multicolumn{2}{|c|}{$\begin{array}{l}\text { Потери на ис- } \\
\text { парение с } \\
\text { зеркала водо- } \\
\text { хранилищ }\end{array}$} & $\begin{array}{c}\text { Потери из } \\
\text { прудов и во- } \\
\text { дохранилищ } \\
\text { на притоках }\end{array}$ \\
\hline 42,34 & 6,81 & & 1,67 & \multicolumn{2}{|c|}{0,26} & \multicolumn{2}{|l|}{18} & 15,6 \\
\hline \multicolumn{9}{|c|}{ ранилищ (в среднем за многолетие) } \\
\hline \multicolumn{9}{|c|}{ В Т. Ч.: } \\
\hline Всего & $\begin{array}{l}\text { филь- } \\
\text { трация }\end{array}$ & \multicolumn{3}{|c|}{$\begin{array}{c}\text { компенсационный } \\
\text { транзит для нижерас- } \\
\text { положенного водо- } \\
\text { хранилища }\end{array}$} & \multicolumn{4}{|c|}{$\begin{array}{c}\text { холостой сброс, включая технологиче- } \\
\text { ский расход для обеспечения нормаль- } \\
\text { ной работы судоходной плотины } \\
\text { Усть-Манычского ГУ }\end{array}$} \\
\hline 1101,09 & 14,19 & \multicolumn{3}{|c|}{4,71} & \multicolumn{4}{|c|}{1142,79} \\
\hline
\end{tabular}

\section{Выводы}

1 Западный отсек Пролетарского водохранилища расположен между Пролетарским гидроузлом и Ново-Манычской дамбой и представляет собой плес длиной около 20 км. Занимает командное положение по высоте всех водохранилищ на р. Западный Маныч. В нормальных условиях экс- 
плуатации через водорегулирующее сооружение в Ново-Манычской дамбе происходит отток воды из западного отсека в восточный. Основное количество воды в западный отсек поступает по р. Егорлык, она сбрасывается через водоспуск плотины Пролетарского гидроузла в Веселовское водохранилище. В связи с этим требуется особое регулирование стока р. Егорлык через пятисекционное сооружение Ново-Манычской дамбы в виде плоских затворов.

2 На третьем этапе (1965-1975 гг.) была построена в устье р. Калаус дамба, перекрывающая сток р. Калаус в р. Восточный Маныч. В результате полностью весь сток р. Калаус стал поступать в р. Западный Маныч.

3 На четвертом этапе (1980-1995 гг.) оз. Маныч-Гудило стало бессточным водоемом. На р. Западный Маныч (в месте истока) сооружена глухая дамба с фиксированным порогом. Поэтому сток р. Калаус поступает в полном объеме в оз. Маныч-Гудило, а переток высокоминерализованных вод из оз. Маныч-Гудило в Пролетарское, Веселовское и УстьМанычское водохранилища не осуществляется.

4 Максимальные допустимые расходы через водопропускные сооружения гидроузла Пролетарского водохранилища и их допустимые сочетания определяются из условий оптимального гидравлического режима работы сооружений и гашения водной энергии, а также характеристик приточных расходов.

5 Научная новизна исследований Пролетарского водохранилища состоит в использовании Ново-Манычской дамбы, которая разделяет водохранилище на два отсека - западный и восточный. При этом регулирующая роль отсеков заключается в поступлении воды через водорегулирующее сооружение, состоящее из пяти пролетов с затворами, в восточный отсек.

\section{Список источников}

1. Хоружая Т. А., Минина Л. И. Оценка экологического состояния Цимлянского, Пролетарского и Веселовского водохранилищ // Метеорология и гидрология. 2017. № 5. C. 116-122. 
Мелиорация и гидротехника. 2021. Т. 11, № 4. С. 346-359.

Land Reclamation and Hydraulic Engineering. 2021. Vol. 11, no. 4. P. 346-359.

2. Акопян А. В., Слабунов В. В. Потенциал каскада Манычских водохранилищ в разрезе развития орошаемого земледелия на Нижнем Дону // Комплексные мелиорации - средство повышения продуктивности сельскохозяйственных земель: материалы юбилейн. междунар. науч.-практ. конф., 26-27 нояб. 2014 г. М., 2014. С. 337-342.

3. Штанько А. С., Акопян А. В., Сафарова А. В. Обобщение и анализ нормативных документов, определявших режим использования водных ресурсов Пролетарского, Веселовского и Усть-Манычского водохранилищ // Научный журнал Российского НИИ проблем мелиорации [Электронный ресурс]. 2012. № 1(05). URL: http:www.rosniipmsm.ru/dl_files/udb_files/udb13-rec98-field6.pdf (дата обращения: 01.08.2021).

4. Бандурин М. А. Эксплуатационный мониторинг и остаточный ресурс водопроводящих сооружений мелиоративных систем. Изд. 2-е, перераб. и доп. Новочеркасск: Лик, 2016. 233 с.

5. When timing matters-misdesigned dam filling impacts hydropower sustainability / M. Zaniolo, M. Giuliani, S. Sinclair, P. Burlando, A. Castelletti // Nature Communications. 2021. Vol. 12(1). Article number: 3056. DOI: 10.1038/s41467-021-23323-5.

6. Исследования потенциально промысловых районов Ростовской области в 2014-2015 гг. / Е. М. Саенко, С. А. Кузнецов, Г. В. Головко, Е. Е. Чубова // Труды АЗНИИРХ (результаты рыбохозяйственных исследований в Азово-Черноморском бассейне): сб. науч. тр. Ростов н/Д., 2017. С. 116-122.

7. Баев О. А., Гарбуз А. Ю., Шкура В. Н. Рыбоводный комплекс на базе оросительно-обводнительного канала и малой реки // Пути повышения эффективности орошаемого земледелия. 2018. № 2(70). С. 151-156.

8. Экологический вестник Дона. О состоянии окружающей среды и природных ресурсов Ростовской области в 2019 году. Ростов н/Д., 2020. 372 с.

9. Гурин К. Г., Григор А. Н. Современное состояние Манычских водохранилищ // Проблемы создания устойчивых природных ландшафтов России: материалы науч.-практ. конф. студентов и молодых ученых. 2004. С. 138-141.

10. Позняк В. Г., Рыбакова А. В. К оценке рыбохозяйственной ситуации на Пролетарском водохранилище // Вестник Калмыцкого института социально-экономических и правовых исследований. 2005. Т. 2, № 2. С. 103-109.

11. Nikanorov A. M., Khoruzhaya T. A. The role of biotic and abiotic component of the aquatic ecosystems in the formation of ecological trouble in Tsimlyansky and Manychsky reservoirs // Water Resources. 2019. Vol. 46(5). P. 759-768. DOI: 10.1134/S0097807819050178.

12. Панов В. Д., Базелюк А. А., Лурье П. М. Реки Западный и Восточный Маныч: гидрография и режим стока. Ростов н/Д.: Дон. изд. дом, 2009. 430 с.

13. Водные ресурсы. Природные и производственные силы Северного Кавказа. Ростов н/Д.: Изд-во Рост. ун-та, 1981. 248 с.

14. Волосухин В. А. О прогнозе водности рек Южного федерального округа // Проблемы и перспективы развития мелиорации, водного и лесного хозяйства (к 75-летию РАСХН): сб. науч. тр. / Россельхозакадемия. М.: ВНИИА, 2004. С. 154-158.

\section{References}

1. Khoruzhaya T.A., Minina L.I., 2017. Otsenka ekologicheskogo sostoyaniya Tsimlyanskogo, Proletarskogo $i$ Veselovskogo vodokhranilishch [Assessment of the ecological state of the Tsimlyansk, Proletarsk and Veselovsk reservoirs]. Meteorologiya i gidrologiya [Meteorology and Hydrology], no. 5, pp. 116-122. (In Russian).

2. Akopyan A.V., Slabunov V.V., 2014. Potentsial kaskada Manychskikh vodokhranilishch $v$ razreze razvitiya oroshaemogo zemledeliya na Nizhnem Donu [Potential of the Manych reservoirs cascade in the context of irrigated agriculture development in the Lower Don]. Kompleksnye melioratsii - sredstvo povysheniya produktivnosti sel'skokhozyaystven- 
Мелиорация и гидротехника. 2021. Т. 11, № 4. С. 346-359.

Land Reclamation and Hydraulic Engineering. 2021. Vol. 11, no. 4. P. 346-359.

nykh zemel': materialy yubileynoy mezhdunarodnoy nauchno-prakticheskoy konferentsii [Complex Reclamation - a Means of Increasing the Productivity of Agricultural Lands: Proc. of the Jubilee International Scientific-Practical Conference], pp. 337-342. (In Russian).

3. Shtanko A.S., Akopyan A.V., Safarova A.V., 2012. [Generalization and analysis of regulatory documents for usage mode of water resources of the Proletarskiy, Veselovsky and Ust'-Manychsky reservoirs]. Nauchnyy Zhurnal Rossiyskogo NII Problem Melioratsii, no. 1(05), available: http:www.rosniipm-sm.ru/dl_files/udb_files/udb13-rec98-field6.pdf [accessed 01.08.2021]. (In Russian).

4. Bandurin M.A., 2016. Ekspluatatsionnyy monitoring $i$ ostatochnyy resurs vodoprovodyashchikh sooruzheniy meliorativnykh sistem [Operational Monitoring and Residual Life of Water-Conveyance Structures of Reclamation Systems]. $2^{\text {nd }}$ ed., rev. and add. Novocherkassk, Lik Publ., 233 p. (In Russian).

5. Zaniolo M., Giuliani M., Sinclair S., Burlando P., Castelletti A., 2021. When timing matters-misdesigned dam filling impacts hydropower sustainability. Nature Communications, vol. 12(1), article number: 3056, DOI: 10.1038/s41467-021-23323-5.

6. Saenko E.M., Kuznetsov S.A., Golovko G.V., Chubova E.E., 2017. Issledovaniya potentsial'no promyslovykh rayonov Rostovskoy oblasti v 2014-2015 gg. [Studies of commercially important fishing areas of Rostov region in 2014-2015]. Trudy AZNIIRKH (rezul'taty rybokhozyaystvennykh issledovaniy $v$ Azovo-Chernomorskom basseyne) [Proceedings of AZNIIRKH (Results of Fishery Studies in the Azov-Black Sea Basin)]. Rostov-on-Don, pp. 116-122. (In Russian).

7. Baev O.A., Garbuz A.Yu., Shkura V.N., 2018. Rybovodnyy kompleks na baze orositel'no-obvodnitel'nogo kanala $i$ maloy reki [Fish-breeding complex based on an irrigation and feeding canal and minor river]. Puti povysheniya effektivnosty oroshaemogo zemledeliya [Ways of Increasing the Efficiency of Irrigated Agriculture], no. 2(70), pp. 151-156. (In Russian).

8. Ekologicheskiy vestnik Dona. O sostoyanii okruzhayushchey sredy i prirodnykh resursov Rostovskoy oblasti v 2019 godu [Ecological Bulletin of the Don. On the State of the Environment and Natural Resources of Rostov Region in 2019]. Rostov-on-Don, 2020, 372 p. (In Russian).

9. Gurin K.G., Grigor A.N., 2004. Sovremennoe sostoyanie Manychskikh vodokhranilishch [The current state of the Manych reservoirs]. Problemy sozdaniya ustoychivykh prirodnykh landshaftov Rossii: materialy nauchno-prakticheskoy konferentsii studentov $i$ molodykh uchenykh [Problems of Creating Sustainable Natural Landscapes of Russia: Proc. of Scientific and Practical Conference for Students and Young Scientists], pp. 138-141. (In Russian).

10. Poznyak V.G., Rybakova A.V., 2005. K otsenke rybokhozyaystvennoy situatsii na Proletarskom vodokhranilishche [On assessing the fish-breeding situation in the Proletarian reservoir]. Vestnik Kalmytskogo instituta sotsial'no-ekonomicheskikh i pravovykh issledovaniy [Bulletin of Kalmyk Institute of Socio-Economic and Legal Research], vol. 2, no. 2, pp. 103-109. (In Russian).

11. Nikanorov A.M., Khoruzhaya T.A., 2019. The role of biotic and abiotic component of the aquatic ecosystems in the formation of ecological trouble in the Tsimlyansky and Manychsky reservoirs. Water Resources, vol. 46(5), pp. 759-768, DOI: 10.1134/S0097 807819050178.

12. Panov V.D., Bazelyuk A.A., Lur'ye P.M., 2009. Reki Zapadnyy $i$ Vostochnyy Manych: gidrografiya i rezhim stoka [The Rivers Zapadny and Vostochny Manych: Hydrography and Runoff Regime]. Rostov-on-Don, Don Publ., 430 p. (In Russian).

13. Vodnye resursy. Prirodnye i proizvodstvennye sily Severnogo Kavkaza [Water Resources. Natural and Productive Forces of the North Caucasus]. Rostov-on-Don, Rostov University Publ., 1981, 248 p. (In Russian). 
Мелиорация и гидротехника. 2021. Т. 11, № 4. С. 346-359.

Land Reclamation and Hydraulic Engineering. 2021. Vol. 11, no. 4. P. 346-359.

14. Volosukhin V.A., 2004. O prognoze vodnosti rek Yuzhnogo federal'nogo okruga [On forecasting the water content of rivers in the Southern Federal District]. Problemy i perspektivy razvitiya melioratsii, vodnogo $i$ lesnogo khozyaystva ( $k$ 75-letiyu RASKHN): sb. nauch. tr. [Problems and Prospects for the Development of Land Reclamation, Water and Forestry (to the $75^{\text {th }}$ Anniversary of the Russian Academy of Agricultural Sciences): Proc.]. Russian Agricultural Academy, Moscow, VNIIA, pp. 154-158. (In Russian).

\section{Информация об авторах}

Ю. М. Косиченко - главный научный сотрудник, доктор технических наук, профессор; В. Ф. Талалаева - младший научный сотрудник, аспирант.

\section{Information about the authors}

Yu. M. Kosichenko - Chief Researcher, Doctor of Technical Sciences, Professor; V. F. Talalaeva - Junior Researcher, Postgraduate Student.

Авторы заявляют об отсутствии конфликта интересов.

The authors declare no conflicts of interests.

Статья поступила в редакциию 02.07.2021; одобрена после рецензирования 12.10.2021; принята к публикации 14.10.2021.

The article was submitted 02.07.2021; approved after reviewing 12.10.2021; accepted for publication 14.10.2021. 